Open Access to Pharmaceutical and Medical Research

(C) 2011-18, publisher and licensee JDDT, This is an Open Access article which permits unrestricted non-commercial use, provided the original work is properly cited

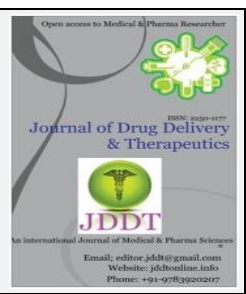

Open $\bigcirc$ Access

Review Article

\title{
Review on Glycyrrhiza glabra L. (Așl al-Sūs) with Unani Perspective and Modern Pharmacology
}

\author{
Gulnaz Fatima ${ }^{1 *}$, Arzeena Jabeen'2, Shahid A. Siddiqui ${ }^{3}$, Mohammad Khalid ${ }^{4}$ \\ ${ }^{1}$ PG Scholar Deptt. of Mu'āljāt, Central Research Institute of Unani Medicine, AG, Colony Road, Erragadda, Hyderabad, India \\ ${ }^{2}$ Lecturer Deptt. of Mu'āljāt, Central Research Institute of Unani Medicine, AG, Colony Road, Erragadda, Hyderabad, India \\ ${ }^{3}$ Asst. Prof. Dept. of Pediatrics, Motilal Nehru Medical College, Allahbad, India \\ ${ }^{4}$ Lecturer, Luqman Unani Medical College, Bijpur, India
}

\begin{abstract}
Traditional Unani (Greco-Arab) medicine is among the most ancient therapies founded by the father of Western medicine, the Hippocrates. Presently, most of the population worldwide depend on herbal medicines for some aspect of their primary health care needs. Treatment with medicinal plants is appraised very safely as there are no or minimal side effects. The promising fact is that herbal treatment can be used irrespective of any age group. Most of the pharmaceutical companies are currently conducting extensive research on plant materials assemble from the rain forests and other places for their potential medicinal value. Glycyrrhiza glabra L. (Leguminosae/Fabaceae) is best known for its use in making licorice-flavored confectionery. In Unani medicine, it is commonly known as Așl al-Sūs. It is a plant of remote origin. Așl al-Sūs extracts and its principle element "glycyrrhizin" have widely been used in foods, tobacco and for medicinal purposes in herbal and traditional medicines as well. It possesses multiple pharmacological and medicinal activities such as anti-ulcer, anti-inflammatory, anti-viral and hepatoprotective actions. This review attempts to compile the data regarding its ethnobotanical actions and medicinal use s in Unani medicine along with its phyto-pharmacological descriptions.
\end{abstract}

Keywords: Herbal medicine, Așl al-Sūs., Glycyrrhiza glabra L.

Article Info: Received 11 June 2019; $\quad$ Review Completed 25 July 2019; $\quad$ Accepted 02 August 2019; Available online 22 August 2019

Cite this article as:

Fatima G, Jabeen A, Siddiqui SA, Khalid M, Review on Glycyrrhiza glabra L. (Așl al-Sūs) with Unani Perspective and Modern Pharmacology, Journal of Drug Delivery and Therapeutics. 2019; 9(4-s):736-741

http://dx.doi.org/10.22270/jddt.v9i4-s.3310

물ㄹ *Address for Correspondence:

Gulnaz Fatima, PG Scholar, Deptt. of Mu'āljāt, Central Research Institute of Unani Medicine, AG Colony Road, Opp. ESIC Hospital, Erragadda, Hyderabad, Telangana, 50038

\section{Introduction}

The herbal products have extensively been used for the thousands of years for amelioration of human sufferings both in the developed and developing countries due to their natural origin and lesser side effects[1] . Even today, when the acceptance of conventional medicine is on its peak corroborated with scientific evidences, the traditional herbal treatment holds the sway among the masses due to its negligible untoward effects, effectiveness in management of chronic morbidities, lower cost, and widespread availability ${ }^{[2]}$. With the persistent demand and use of herbal medicines by the patients in various ailments, various countries have come out with political commitment and technical support for the evolution and propagation of indigenous medicines[3].
This overwhelming support may be attributed to the development of advanced technologies for verification of phyto-chemical and pharmacological actions of plants in numerous pathological conditions ${ }^{[2]}$.

Unani system of medicine is an ancient traditional medicine founded almost 2500 years ago in islands of Cos, Greece on the hands of Hippocrates[4]. The uniqueness of this system is the individualistic but holistic approach in disease prevention and management[5] .

Așl al-Sūs. is a popular herbal drug of Unani medicine. Its botanical name is Glycyrrhiza glabra L. of the Fabaceae family. The common names are licorice and sweet wood. Its root (Bikh-i-Așl al-Sūs.) and extract (Rub al-soos) are widely used for the treatment of various diseases[6,7].

According to Ibn Baitar, Așl al-Sūs. is the drug of choice for respiratory and bladder diseases, such as burning 
micturition and burning sensation in the chest. It is also used in treatment of cold-tempered ailments; Amrāde-i Balghamiyā and Sawdāwiā (phlegmatic and melancholic disorders), such as Sar' (epilepsy), Fālij (hemiplegia), Laqwa (facial palsy), Qabūs (nightmare), Tawaḥhush (anxiety), Mālikholia (Melancholia), Khushunat-i Halaq (sore throat), Bohat alSawt Hād (acute hoarseness of voice), Warm-i Luhāt (uvulitis), Warm-i Sho'ba al-Riyā (bronchitis), Dìq al-Nafas (asthma), Sū'al-i Yābis (dry cough) etc[7-13]. Aṣl al-Sūs. has experimentally been proved for various pharmacological actions, such as anti-bacterial, anti-hepatotoxic, anti-fungal, and anti-oxidant; anti-hyper-glycemic, anti-viral, anti-ulcer, estrogenic, anti-diuretic, and immuno-stimulant activities. It has also been found effective in cure of psoriasis, eczema, and herpes simplex[14,15].

The important chemical constituents are flavonoids, coumarins, volatile oils, terpenoids, and amino acids which have been isolated from the plant $\operatorname{root}^{[6,8,16]}$. However, the reported adverse effects are liver, spleen and kidney derangements. In Unani medicine, its roots are used only after peeling the bark (Așl al-Sūs. Muqash'shar) which dramatically decreases its toxic effects.

\section{Scientific classification[17]}

$\begin{array}{ll}\text { Kingdom: } & \text { Plantae } \\ \text { Subkingdom: } & \text { Tracheobionta } \\ \text { Division: } & \text { Magnoliophyta } \\ \text { Class: } & \text { Magnoliopsida } \\ \text { Subclass: } & \text { Rosidae } \\ \text { Order: } & \text { Fabeles } \\ \text { Family: } & \text { Fabaceae } \\ \text { Genus: } & \text { Glycyrrhiza } \\ \text { Species: } & \text { G. glabra } \\ \text { Botanical name: } & \text { Glycyrrhiza glabra L. }\end{array}$

Vernacular names: $[6,7,9,10,16,18]$

Arabic: Așl al-Sūs.; Irq al-sūs; Ood al-sūs; 'Uruq al-soos

English: Licorice; Liquorice root; Sweet wood

French: Boisdoux

German: Sussholz

Greek: Glycyrrhiza

Hindi: Mulethi; Mulathi; Muleti; Jethimadhu; Jethimadhu; Mulhatti

Kannada:Atimadhura; Yeshtimadhuka

Kashmiri:Multhi; Shanger

Malayalam: Athimadhuram; Irattimadhuram; Yeshtimadhuram

Marathi: Jeshthamadha

Oriya: Jastimadhu; Jatimadhu

Persian: Bikh-i-Mehak; Bikh-i-Ribas; 'Usara-mehak

Punjabi: Jethimadh; Mulathi

Sanskrit: Madhuka; Yashtimadhu; Sinhale: Welmi

Tamil: Athimadhuram; Antimadhuram

Telegu: Atimadhuramu; Yashtimadhukam

Urdu: Mulethi

Dioscorides is credited for coining the name Glychyrrhiza which is composed of two Greek words implying sweet root. The specific name glabra indicates its smooth surface without hairs.
Distribution: The plant is native to the Mediterranean region; it is cultivated in Iran; Afghanistan, and Europe. No liquorice yielding species is found in India; although, the cultivation of G. glabra L. has been undertaken at several places on an experimental basis such as Baramulla; Srinagar; Delhi; Dehradun, and hilly areas of South India[6,8,18,19]

Description in Unani Literatures: Asl-ul-soos is a dried, unpeeled or peeled root and shoot of Glycyrrhiza glabra L. of Leguminosae family. It extends up to 2-meter height; flowers vermilion blue; leaves mimic with Kasondi (Cassia occidentalis); small legumes arise on the branches which carry 4-5 seeds; roots spread 1 meter in soil; smell unclear and unique; taste sweet then bitter [7,9].

\section{Morphology}

\section{Macroscopic:}

Root: Cylindrical root pieces,14-20 cm in length, $5-20 \mathrm{~cm}$ in width, surface irregular, longitudinally wrinkled, at places shows scars left by removal of the lateral roots; fracture outer fibrous and inner splintery; externally dark brown; internally golden yellow; transversally cut surface exhibits wide central xylem, cambium ring, outer narrow phloem, and wide radiating medullary rays. Taste is sweet; odor is unclear and unique $[6,8,20]$.

Stolon: Cylindrical, unbranched, straight, variable in length,1-2 cm in diameter; it consists of yellowish brown or dark brown outer layer; externally longitudinal wrinkled with occasional small buds and encircling scale leaves; smoothed transversely; the cut surface shows a cambium ring about one -third of radius from outer surface and a small central pith ${ }^{[6,8,20]}$.

\section{Microscopic:}

Stolon: Transverse section of stolon shows cork of 10-20 or more layer of tabular cells, outer layers with reddish-brown amorphous contents, Inner 3 or 4 rows having thicker; colorless walls; secondary cortex usually of 1-3 layers of radially arranged parenchymatous cells containing isolated prism of calcium oxalate; $2^{0}$ phloem a broad band; cells of inner part cellulosic and outer lignified; radially arranged group of about 10-50 fibers surrounded by a sheath of parenchyma cells, each usually containing a prism of calcium oxalate about 10-35 m long cambium form tissue of 3 or more layers of cells; secondary xylem distinctly radiate with medullary rays,3-5 cells wide; vessels about $80-200 \mathrm{~m}$ in diameter with thick, yellow, pitted, reticulately thickened walls; groups of lignified fibers with crystal sheath similar to those of phloem; xylem parenchyma of two kinds, those between vessels having thick pitted walls without intercellular spaces, the remaining with thin walls; pith of parenchymatous cell in longitudinal rows, with intercellular spaces. $[6,8,20]$

Root: Transverse section of root shows structure closely resembling to that stolon except that no medulla is present; xylem tetrarch; usually principal medullary rays are at right angles to each other; in peeled drug cork shows phelloderm and sometimes without secondary phloem; all parenchymatous tissues containing abundant, simple, oval or rounded starch grains that are $2-20 \mathrm{~m}$ in length $[6,8,20]$.

\section{Phytochemical Constituents $[6,8,16,18]$}
$>$ Amino acids
$>$ Asparagine
$>$ Bitters
$>$ Coumarin 
$>$ Essential oil

$>$ Female hormone estrogen

$>$ Fat

$>$ Flavonoids

$>$ Glycosides

$>$ Glycyrrhizin (main constituent found in the root)

$>$ Gums

$>$ Glycyrrhetic acid

$>$ Mucilage (rhizome)

$>$ Protein

$>\operatorname{Resin}$

$>$ Saponoids

$>$ Saponins

$>$ Sterols

$>$ Starches $(30 \%)$

$>$ Sugars (up to $14 \%$ ) when mixed with water or used in cough drops

$>$ Tannin

$>$ Volatile oil.

\section{Pharmaco-kinetic studies}

After oral administration of licorice in humans, the main constituent glycyrrhizic acid is hydrolyzed into glycyrrhetic acid by intestinal bacteria possessing a specialized $\beta$ glucuronidase[21,22]. Glycyrrhetic acid is 200-1,000 times more powerful inhibitor of 11- $\beta$-hydroxy-steroid dehydrogenase involved in corticosteroid metabolism than glycyrrhizic acid. Hence, its pharmacokinetic after oral intake are too appropriate. After oral dosing, glycyrrhetic acid is promptly absorbed and transported through carrier molecules to the liver, and metabolized into glucuronide and sulfate conjugates, which are eventually hydrolyzed to glycyrrhetic acid. Glycyrrhetic acid is then reabsorbed, resulting in an important hamper in terminal clearance from plasma [23]. After oral administration of $100 \mathrm{mg}$ glycyrrhizin in healthy volunteers, no glycyrrhizin was found in the plasma but glycyrrhetic acid was found at $<200 \mathrm{ng} / \mathrm{mL}$ [23]. In the 24-hour period after oral administration, glycyrrhizin was observed in the urine which indicates that it is partly absorbed as an intact molecule.[24]

Mechanism of Action: Glycyrrhizin and glycyrrhizic derived from Glychyrrhiza glabra have been found for suppressing development of various infections including hepatitis $\mathrm{A}$ and C; HIV; herpes zoster; CMV, and Herpes simplex[25,26] Glycyrrhizin and its metabolites are reported to suppress the aldosterone and smother $5 \beta$ reductase in pseudoaldosterone disorder. The similarity in the structure of glycyrrhetic acid to the structure of hormones discharged by the adrenal cortex highlights the mineralocorticoid and glucocorticoid action of glycyrrhizin corrosive[27,28].

Mizāj (temperament): Unani scholars have differed in identification of its temperament as under:

- Hot and dry[9]

- Ibn Sina and Kirmānī considered it moderate or Murakkab-ul-Quwa

- $\quad$ Some regarded it hot 10 and wet10[29]

- Hot $2^{0}$ and dry10[9]

Parts used: root[29]

Dose:: 3-7 gm[9] ; 5-10 gm[30]

Adverse effects: it may cause or aggravate diseases of liver, kidney, and spleen[10,30,31]

Corrective: Gul-e-Surkh (Rosa demascena) in case of splenic toxicity; Samagh-i-Katira (Gum Traga cantha) in diseases of kidney[9,30].

\section{Substitute:[10,30]}

- $\quad$ Rubb-al-sūs (extract of root of Glycyrrhiza glabra L.)

- $\quad$ Turbud (Ipomoea terpthum)

- Zanjabil (Zingiber officinale)

- Khulanjan (Alpinia galanga)

- In case of headache, Samagh-i-Katira (Gum Traga cantha) is used as substitute.

Pharmacological actions of Glycyrrhiza glabra L. (Aṣl al-Sūs.) in Unani medicine and Ethno-medicine

\begin{tabular}{|c|c|c|c|}
\hline \multicolumn{4}{|c|}{ Table 1: Pharmacological action of Glycyrrhiza glabra L. (Așl al-Sūs.) } \\
\hline S. No. & Action & Unani Reference & Ethno-botanical Reference \\
\hline 1. & Resolvent (Muhallil-i-Warm) & {$[8,30]$} & [32] \\
\hline 2. & Demulcent (Mulațtif) & {$[8,10]$} & {$[17,33]$} \\
\hline 3. & Expectorant (Munaffith-i-Balgham) & {$[8,17]$} & [34] \\
\hline 4. & Detergent (Jālì & {$[8,10]$} & {$[35]$} \\
\hline 5. & Carminative (Kasīr-i-Riyāh & {$[8,36]$} & \\
\hline 6. & Nervine tonic (Muqawwi-i-Asab) & {$[8,17,36]$} & [34] \\
\hline 7. & Emmenagogue (Muddirr-i-hayḍ) & {$[8,17,29]$} & [34] \\
\hline 8. & Laxative (Mulayyin) & {$[36]$} & {$[17]$} \\
\hline 9. & Diuretic (Mudirr-i-bawl) & {$[8,10,36]$} & [35] \\
\hline 10. & Antipyretic (Daf-i-Hummā) & {$[8,10]$} & \\
\hline 11. & Anti-anxiety (Daf-i-Tawahhush), & {$[10]$} & \\
\hline 12. & Emollient & & {$[37]$} \\
\hline
\end{tabular}


Therapeutic uses in Unani and Ethno-medicine

\begin{tabular}{|c|c|c|c|}
\hline \multicolumn{4}{|c|}{ Table 2: Therapeutic uses of Glycyrrhiza glabra L. (Așl al-Sūs.) } \\
\hline S. No. & Uses & Unani reference & Ethno botanical references \\
\hline 1. & Gastric ulcers (Qarha-i-mi'da) & {$[11,12]$} & [38] \\
\hline 2. & Duodenal ulcers (Qarha-i-Ashnā-i-Ashri) & {$[11,12]$} & [38] \\
\hline 3. & Sore throat (Khashūnat al-Halq) & {$[8,12]$} & [39] \\
\hline 4. & Bronchitis (Warm-i-Sho'ba al-Riyya) & {$[8,12]$} & [39] \\
\hline 5. & Asthma (Dìq al-Nafas) & {$[7,9,10]$} & [39] \\
\hline 6. & Rheumatoid Arthritis (Waj al Mafașill) & & {$[40]$} \\
\hline 7. & acute hoarseness of voice (Buhha al-Ṣawth) & {$[7,9,10]$} & [41] \\
\hline 8. & Dry cough (Suāl-i-yābis) & {$[13]$} & {$[40]$} \\
\hline 9. & Epilepsy (Sar) & {$[7,9,10]$} & {$[34]$} \\
\hline 10. & Hemiplegia (Fālij) & {$[7,9,10]$} & \\
\hline 11. & Facial palsy (Laqwa) & {$[12,13]$} & \\
\hline 12. & Nightmare (Qābūs) & {$[12,13]$} & \\
\hline 13. & Anxiety (Tawahhush) & {$[7,10,13]$} & \\
\hline 14. & Melancholia (Malānkhūliya) & {$[9,12]$} & \\
\hline 15. & Hemorrhoids (Bawāsīr) & {$[7]$} & \\
\hline 16. & Burning micturition (Hurqa al-bawl) & {$[7,9,10]$} & \\
\hline 17. & Uvulitis (Warm-i-luhät) & {$[7,9,13]$} & \\
\hline 18. & Stomatitis (Qulä') & {$[7,9,10]$} & \\
\hline 19. & Gonorrhea (Suzāk) & {$[12,13]$} & \\
\hline 20. & Abdominal pain (Waja al-mi'da) & {$[9,12]$} & {$[34]$} \\
\hline 21. & Hypertension (Zaghtuddam Qawi) & & {$[42]$} \\
\hline 22. & Foul perspiration of the armpit & {$[7]$} & [34] \\
\hline
\end{tabular}

Pharmacological evidence/ experimental studies

\begin{tabular}{|c|c|c|c|}
\hline $\begin{array}{l}\text { S. } \\
\text { No. }\end{array}$ & Activity & Part/Extract & Cell lines/Animal model \\
\hline 1. & Anti-inflammatory & Hydroalcoholic extract & $\begin{array}{l}\text { Carrageenan induced rat paw edema at dose levels of } 100,200,300 \\
\mathrm{mg} / \mathrm{Kg} \text {. The extract showed a maximum of } 46.86 \% \text { inhibitory } \\
\text { action[43] }\end{array}$ \\
\hline 2. & Immunomodulatory & Aqueous extract & $\begin{array}{l}\text { In vivo phagocytosis, determination of cellular immune response } \\
\text { hemagglutination antibody titer \& plaque forming cell assay using } \\
\text { sheep RBCs [44] }\end{array}$ \\
\hline 3. & Antiulcer & $\begin{array}{l}\text { Aqueous, acetone, } \\
\text { ethanolic extracts of } \\
\text { leaves }\end{array}$ & $\begin{array}{l}\text { Micro-organism used: Helicobacter pylori by agar well diffusion } \\
\text { method[45] }\end{array}$ \\
\hline 4. & Anti-tussive & Ethanol extract & $\begin{array}{l}\text { SO2 gas induced cough in experimental animals. Mice showed an } \\
\text { inhibition of } 35.62 \% \text { in cough on treatment with G. glabra extract } \\
{[46]}\end{array}$ \\
\hline 5. & $\begin{array}{l}\text { Chronic fatigue } \\
\text { stress }\end{array}$ & Hydroalcoholic extract & $\begin{array}{l}\text { The extract showed the protective effect on mice on exposure to } \\
\text { chronic fatigue stress }[47]\end{array}$ \\
\hline 6. & Antimicrobial & $\begin{array}{l}\text { Ether, Chloroform, } \\
\text { acetone }\end{array}$ & Micro-organisms used: E. coli, B. subtilis, P. aerogenosa, S. aureus ${ }^{[48]}$ \\
\hline 7. & Cytotoxic & $\begin{array}{l}\mathrm{CHCl} 3 \text {, methanol \& } \\
\text { aqueous extract }\end{array}$ & $\begin{array}{l}\text { In vitro cytotoxic activity using two different cell lines MCFT- } \\
\text { cancerous \& Vero-normal cell line [49] }\end{array}$ \\
\hline 8. & Anticonvulsant & methanol extract of leaves & $\begin{array}{l}\text { Fractions were evaluated intra-peritoneally in mice using maximal } \\
\text { electroshock (MES) \& pentylenetetrazol (PTZ) seizure tests }[50]\end{array}$ \\
\hline 9. & Antiviral & Aqueous extract & Herpes simplex 1 \& vesicular stomatitis virus [51] \\
\hline 10. & Anticancer & Licorice extract & Ames test, Trp-p-1, Trp-p-2 in S.typhimurium TA 98 reverants[52] \\
\hline 11. & Enzyme inhibiting & Methanolic extract & In-vitro inhibition of tyrosinase enzyme[53] \\
\hline 12. & Hepatoprotective & Aqueous extract of roots & $\begin{array}{l}\text { PCM induced rats' hepatocytes damage in vivo. Rabbit models with } \\
\text { acute liver injury induced by CCl4 [54] }\end{array}$ \\
\hline 13. & Memory enhancing & Aqueous extract of roots & $\begin{array}{l}\text { Three-month-old Wistar albino rats. Elevated -plus maze and } \\
\text { Morris water -maze test were conducted[55] }\end{array}$ \\
\hline 14. & Antioxidant & Methanol extract & $\begin{array}{l}\text { The method based on scavenging activity \& reduction capability of } \\
\text { 1,1-diphenyl-2-picrylhydrazyl radical; Also against nitric oxide \& } \\
\text { superoxide radicals [56] }\end{array}$ \\
\hline 15. & Anti-stress activity & $\begin{array}{l}\text { Alcoholic \& aqueous } \\
\text { extract }\end{array}$ & $\begin{array}{l}\text { Reduce stress in Drosophila melanogaster induced by Methotrexate } \\
\text { at different conc }{ }^{[5]}\end{array}$ \\
\hline
\end{tabular}


Compound formulations: Various compound formulations have been mentioned in Unani medicine containing Așl alSūs., and these compounds are:

Dayaquza; Haḅb-i-Baqla; Haḅb-i-Sū'al Musakkin; Haḅb-i -iGhariqun; Habb-i-Nazla; Habb-i-Surfa Qawi; Jawarish Așl al sūs; Joshandah Munzij; Lauq Sapistan; Lauq Amaltas; Lauq Khiyar Shmabar; Lauq Sapistan; Lauq Shamoon; Lauq Hulba; Lauq Ziq-un-Nafas; Majun Mughalliz Jawaharwali; Majun Mundi; Marham Kafoor; Namak Sulemani; Qabzeen; Qurs-iGul; Qurs-i-Su'al; Qairūtī Aarad Karsana; Qurs-i-Mullayyin; Qurs-i-Sartan Kafoori; Qurs-i-Zarishk; Roghan Sanan; Satawari; Sharbat Sadar; Sharbat Aijaz [58-60]

\section{Conclusion:}

Așl al-Sūs is one of the most important plant Glycyrrhiza glabra L. (Leguminosae/Fabaceae) which has been used by Unani physicians for the treatment of various diseases. The modern experimental and clinical pharmacological studies confirmed also anti-inflammatory, immuno-modulatory, antiulcer, anticonvulsant, memory-enhancing activities etc.

From this evidence-based review it can be concluded that new research avenues may validate scientifically the use of Glycyrrhiza glabra L. in amelioration of various diseases as described by Unani scholars.

\section{References:}

1. Abdullahi AA. Trends and challenges of traditional medicine in Africa. Afr J Tradit Complement Altern Med. 2011;8:11523.

2. Ngo, L.T.; Okogun, J.I.; Folk WR. 21st Century natural product research and drug development and traditional medicines. . Nat Prod Rep. 2013;30:584-92.

3. Parasuraman, S.; Thing, G.S.; Dhanaraj SA. Polyherbal formation: Concept of ayurveda. Pharmacogn Rev. 2014;8:7380.

4. Lone, A.H.; Ahmad, T.; Anwar, M.; Sofi, G.; Imam, H.; Habib S. Perception of health promotion in Unani herbal medicine. J Herb Med. 2012;2.

5. Jabin FA. A guiding tool in Unani Tibb for maintenance and preservation of health: A review study. Afr J Tradit Complement Altern Med. 2011;8:140-3.

6. Anonymous. The Wealth of India, A Dictionary of Indian Raw Material and Industrial Products. New Delhi: CSIR; 2005. 151$153 \mathrm{p}$.

7. A. H. Bustān al-Mufradāt. New Delhi: Aijāz Publising house; 2011. $317 \mathrm{p}$.

8. Anonymous. Unani Pharmacopoeia of India. New Delhi Department of AYUSH, Ministry of Health \& Family Welfare, Govt. of India; 2007. 03.

9. Ghanī. Khazā' in al-Adwiya. New Delhi: Iādra Kitāb al-Shifā; 2011. $1260-1261 \mathrm{p}$.

10. M K. Ilmul Adwiya Nafīsī. New Delhi: Aijāz. Publishing Housep; 2007. $232 \mathrm{p}$

11. Zuhr I. Kitāb al-Taysīr fil Mudāwāt wā Tadbīr (Urdu translation). 1st ed. New Delhi: CCRUM Ministry of Health and Family Welfare; $1986.204-5$ p.

12. Kabir al-Din M. Makhzan al-Mufradat,. New Delhi: Aijaz Publishing House; 2014. 390-391 p.

13. I. B. al-Jāmi' li Mufradāt al-Adwiya wa al-Aghdhia, vol. 03,, (Urdu Trans: New Delhi: Central Council for Research in Unani Medicine), Department of AYUSH, Ministry of Health and Family Welfare, Govt. of India; 1999. 98-99 p.

14. Olukoga A DD. Historical perspectives on health. The history of liquorice: the plant, its extract, cultivation, and commercialization and etymology of the Royal Society of
Health. 1998;118:300-4.

15. Rastogi RP MB. Compendium of Indian Medicinal Plants. New Delhi: Rastogi: National Institute of Science Communication and Information Resources; 2008. 215-719 p.

16. Jayweera. Medicinal Plants Indigenous and exotic use in Ceylon, The National Science Foundation of Srilanka, Colombo. Colombo; $1981.210 \mathrm{p}$.

17. K.M. N. Indian Materia Medica. 3rd ed. India: Popular Prakashan Pvt. Ltd; 2013. 141-2, 1108-1113. p.

18. CP K. Indian Medicinal Plants: An Illustrated Dictionary. 1st editio. New Delhi: Springer Pvt; 2007. 289-290.

19. MS W. Vanaspatis in the Service of Humankind. Srinagar: Idris Publications; 2005. 123-124 p.

20. Quality Standards of Indian medicinal plants vol-9. New Delhi: Indian Council of Medical research; 2011. $176 \mathrm{p}$.

21. . Hattori M, Sakamoto T, Yamagishi T et al. Metabolism of glycyrrhizin by human intestinal flora. II. Isolation and characterization of human intestinal bacteria capable of metabolizing glycyrrhizin and related compounds. Chem Pharm Bull. 1985;33:210-217.

22. Akao T, Hattori M et al. Hydrolysis of glycyrrhizin to $18 \beta$ glycyrrhetylmonoglucuronide by lysosomal betaDglucuronidase of animal livers. BiochemPharmacol. 1991;41:1025-9.

23. Ploeger B, Mensinga T, Sips A et al. The pharmacokinetics of glycyrrhizic acid evaluated by physiologically based pharmacokinetic modeling. Drug Metab Rev 2001. 2001;33:125-47.

24. Yamamura Y, Kawakami J, Santa T et al. Pharmacokinetic profile of glycerrhizin in healthy volunteers by a new highperformanceliquid chromatographic method. J Pharm Sci. 1992;81:1042-6.

25. Crance JM, Biziagos E PJ. Inhibition of hepatitis A virus replication in vitro by antiviral compounds. .J Med Virol. 1990;31:155-60.

26. Van Rossum TG, Vulto AG HW. Intravenous glycyrrhizin for the treatment of chronic hepatitis $\mathrm{C}$ : a double-blind, randomized, placebo-controlled phase I/II trial. J Gastroenterol Hepatol. 1999;14:1093-9.

27. Baba M SS. Antiviral activity of glycyrrhizin against Varicellazoster virus in vitro. Antivir Res. 1987;7:99-107.

28. Armanini D, Karbowiak I FJ. Affinity of liquorice derivatives for mineralocorticoid and glucocorticoid receptors. Clin Endocrinol. 1983;19:609-12.

29. N. A. Taj al-Mufradāt. 1st ed. New Delhi: Idāra Kitāb al-Shifā; 2010. 694p.

30. M A. Makhzan al Mufradat ma' Murakkabat wa Khawas al Advia. New Delhi: Aijaz Publishing House,; 2011. 260 p.

31. A N. MufradatNasiri ma Takmila (Persian edition). Azimabad, India: Qaisari Publication; 1880.36 p.

32. Yang R, Wang LQ, Yuan BC LY. The Pharmacological Activities of Liquorice metabolome. Food Chem. 2015;81(18):959-68.

33. $\mathrm{Al} \mathrm{K}$ et. Glycyrrhiza glabra (Liquorice) - a potent medicinal herb. IJPSR. 2013;4(7):2470-7.

34. P.C.Trivedi. Ethnomedicinal plant of india. jaipur: Aavishkar Publishers, Distributors.; 2007. 172,203,242.

35. Zore G, Karuppayil S. Pharmacological Studies on Taverniera Cuneifolia (Roth) Arn: A Substitute for Commercial Liquorice. Academic, LAMBERT; 2016. 212 p.

36. A. HMH. kitabul mufradat

37. Grieve. A Modern Herbal. Penguin; 1984.

38. Lagos. African pharmacopoeia, Vol. 1. 1st. ed. Organization of African Unity, Scientific Technical \& Research Commission; 
1985. 131-134 p.

39. D B. Encyclopaedia of Herbs and their Uses. London: Dorling Kindersley; 1995.

40. Prof.S.K.Bhattacharjee. Handbook of Medicinal Plants. 5th ed. jaipur: Pointer publisher; 2008.171 p.

41. . Lee CK., Park KK. LS. Effects of licorice extracts against tumor growth \& cisplatin induced toxicity in a mouse xenograft model of colon cancer. Biol Pharm Bull. 2007;30:2191-5.

42. PC T. Medicinal plants: utilisation and conservation. 2nd ed. Aavishkar Publishers, Distributors.; 2009. 414,109.

43. Mirmala P. ST. Anti-inflammatory \& antibacterial activities of Glycyrrhiza glabra. J Agric Technol. 2011;7:815-23.

44. . Mazumdar PM., Patnayak SP. PH. Evaluation of immunomodulatory activity of Glycyrrhiza glabra roots in combination with zinc. Asian pacific J Trop Med. 2012;S15-20.

45. Kalaigandhi V. PP. Antimicrobial activity of Glycyrrhiza glabra against peptic ulcer produced Helicobacter pylori. Int J Curr Pharm Res. 2011;3:93-95.

46. Jahan Y. SH. Study of antitussive potential of Glycyrrhiza glabra \&Adhatodavasicausing a cough model induced by SO2 gas in mice. Int J Pharm Sci Res. 2012;3:1668-74.

47. Trivedi R. SK. Hydroalcoholic extract of Glycyrrhiza glabra attenuates chronic fatigue stress induced behavioral alterations in mice. . Int J Pharm Biol Sci. 2011;2:996-1001.

48. Nitalikar M., Munde KC DB. Studies of antibacterial activities of Glycyrrhiza glabra root extract. Int J Pharm Technol Res. 2012;2:899-901.

49. Rathi SG, Suthar M. PP. In vitro cytotoxic screening of Glycyrrhiza glabra. Pharmacology. 2009;1:239-43.

50. Yazdi A., Sardari S. SM. Evaluation of anticonvulsant activity of leaves of Glycyrrhiza glabra grown in Iran as a possible renewable source for anticonvulsant compounds. Iran J Pharm Res. 2011;10(1):75-82.
51. Taro N., Toshio F. TA. Chemistry of phenolic compounds of licorice \& their estrogenic and cytotoxic activities. Journal of Pure \& Applied Chemistry. J Pure Appl Chem. 2002;74:1199_ 206.

52. Lee CK. PK. Effects of licorice extracts against tumor growth \& cisplatin induced toxicity in a mouse xenograft model of colon cancer. Biol Pharm Bull. 2007;30:2191-5.

53. Rastogi RP. MB. Compendium Indian medicinal plants. Publ by CDRI, Lucknow Natl Inst Sci Inf. 1990;94(6):395-8.

54. Al Razzuqii RAM. A-HJ. Hepatoprotective effect of Glycyrrhiza glabra in CCl4 induced model in acute liver injury. J Physiol Pharmacol Adv. 2012;2:259-63.

55. Chakravarthi KK. AR. Effect of Glycyrrhiza glabra root extract on learning \& memory in Wistar albino rats. Drug Invent Today. 2012;4:387-90.

56. Glabra. E of antioxidant \& urease inhibition activity of roots of G. Evaluation of antioxidant \& urease inhibition activity of roots of Glycyrrhiza glabra. Pak J Pharm Sci. 2012;25:99-102.

57. Sowmya M. KS. Antistress property of Glycyrrhiza glabra on stress induced Drosophila melanogaster. J Stress Physiol Biochem. 2010;6:18-27.

58. Anonymous. National Formulary of Unani Medicine, Part VI. New Delhi: Central Council for Research in Unani Medicine, Department of AYUSH, Ministry of Health and Family Welfare, Govt. of India; 2011. 19, 30, 33, 34, 37, 61, 102 p.

59. M. A. Text Book of Pharmacognosy,. 2nd edn. CBC Publication \& Distributors Pvt. Ltd.; 2012.119-121 p.

60. Anonymous. National Formulary of Unani Medicine, Part II, Vol. 1. Central Council for Research in Unani Medicine, Department of AYUSH, Ministry of Health and Family Welfare, Govt. of India New Delhi, 2007b; 19:33. New Delhi: Central Council for Research in Unani Medicine, Department of AYUSH, Ministry of Health and Family Welfare, Govt. of India; 2007. 19,33. 